\title{
Developing Self and Other Recognition: Political Identity in the National Assembly for Wales
}

\author{
Kerry E. Howell \\ Anglia Polytechnic University
}

\begin{abstract}
This article involves a study of political identity in the National Assembly for Wales (NAW). Identity is closely linked with concepts of self in an objective and subjective context and takes a Hegelian idea of recognition in relation to the political identity of the NAW. Identity is explored from both self and other recognition perspectives in relation to the extent the NAW looks beyond the United Kingdom (UK) and concentrates on the European Union $(E U)$ in terms of its identity formulation. For instance, how far is identity recognition in the NAW seen as an EU rather than UK concern? This paper takes into consideration the difficulties regarding a single identity and discusses these in relation to the NAW and Wales in general. This study provides some insight into the changes that devolution brought about and allows a practical and theoretical perspective of the development of Welsh political identity in the NAW.
\end{abstract}

\section{Introduction}

Identity is a complex issue. For instance, it encompasses social experiences, which in the main are influenced by cultural and historical dynamics. However, even though the concept may convey an idea of social solidarity, identity is regularly a contested concept especially when individuals who are assumed to share common values do not. Indeed, differences in values may not correspond with what is considered to be a group's identity. However, when people speak of identity, there is less emphasis on social values and more concern with a primary or core set of values that are assumed to transcend social divisions. Core values that 'can be based on religion, language, race, colour or an assumed common culture' (Bangura, 2001, p.1). Sarup (1996) pointed out that in the past, it was thought that identity and concepts of self persisted throughout political change; while the world changed self and identity remained resolute. In other words, as political 
institutions change social, economic and wider environments, identities change in relation to these fluctuations. Furthermore, Sarup (1996) argued that as 'politics were about the production of identities - politics produces the subjects of its actions' (p.48). In this context, one may ask whether the changes brought about through devolution and the NAW will have an affect on perceptions of self and identity for Welsh people. If the NAW constructs a political identity of its own will this have an affect on Welsh society in general? Indeed, if the NAW was recognised by Whitehall/Westminster and/or Brussels this would probably assist its constituents in identifying themselves with the new institution. Some consider that an NAW that concentrated on promoting the Welsh language might be more successful in developing a Welsh identity than the relevance of the institution externally. However, this paper argues that in the past identity in Wales has been based around language and investigates whether the NAW could incorporate another dimension and along with language provide the basis for an extension or intensification of Welsh identity.

Balsom (1985) argued that the difficulty for Wales was the lack of a common language, religion and/or common culture and that identity in Wales was splintered. Moreover, as Bangura (2001, p.1) says 'The identity of a group is not always easy to determine given differences in the way individuals are socialised during the course of their lives: as members of different families, clans, neighbourhoods, villages, municipalities, professions, social interest groups or transnational organisations'. Balsom (1985) proposed that Welsh claims to a separate identity relied on two main premises: territory and a distinct language based on historical cultural tradition. In the latter case, all Welsh people cannot be classed as Welsh. It may be argued that not everyone in Wales has the same language and/or cultural traditions. However, a distinct territory does exist even though regions within Wales identify specific identities that have continually changed over the last millennium (Davies, 1994; Williams, 1991). Ultimately, Balsom (1985) argued that you have a Welsh identity if you consider yourself to be Welsh; that Welshness is subjective. However, the problem here is Welsh identity in relation to what or whom? To be Welsh or any other group a subjective understanding of self is not enough; there also needs to be an external understanding of self or some form of objective identity recognition, otherwise the concept of having an identity or being Welsh is meaningless.

This article uses a mini-narrative and empirical data to investigate these difficult questions. Initially, the article discusses the concept of identity in relation to the Hegelian idea of recognition, which provides a philosophical basis for the paper's interpretation of identity. Second the article investigates interpretations of political identity in the NAW based on a survey and interviews of AMs. In this context, the author recognises the difficulties in relating these findings to Welsh identity in general. However, if a Welsh political identity exists, is emerging or changing the NAW is an ideal place 
for the investigation to start. This study has limited aims and through a mininarrative investigates the existence of a distinct political identity in the NAW. It discusses some of the difficulties relating to Welsh political identity in a broader sense but considers this issue although relevant to the analysis to be beyond the scope of this study.

\section{Hegelian Recognition and Identity}

This article has an understanding of identity based on ideas of self and other recognition (Hampsher-Monk, 1995; Hegel, 1967; 1971; Kojeve, 1980; Ringmar, 1995). Initially, this is explained in terms of individual identity; however, the paper subsequently uses the concept to outline identity in terms of the wider community.

Kant (1987) attached identity to an abstract self, which was divorced from cultural experience and historical circumstance. Hegel (1971) contended that Kant's idea of self did not exist, because to will was to will something. A self or identity has to exist in relation to some other thing. Hegel labelled the Kantian abstraction Moralität and his own Sittlichkeit. 'While Moralität referred to abstract principles and ought-to-be's Sittlichkeit referred to the existing moral obligations of actual communities. To act in accordance with Sittlicheit was thus necessarily to follow the given social criteria and to perpetuate the already existing' (Ringmar, 1995, p.93). The good life involved the adoption of social roles and participation in social institutions. Usually the state is understood to encapsulate the ideal institution, which allows self-consciousness to become spirit. However, Hegel does not argue that institutions are rational entities in themselves; they are not the unfolding of reason but entities that are made rational through humanity. It is humans that reason or rationalise which types of institutions are necessary for a modern society and this includes the concept of the state. Humans are rational agents and institutions the outcome of rationalisation; consequently, different institutions are appropriate for different situations. This interpretation removes the emphasis from the state as the ideal form and provides arguments for changes in institutional and social structures. In this way, this study explores the views of those rational agents working in a particular institution and makes generalisations regarding these agents to the institution - in this context Assembly Members (AMs) as rational agents in relation to the NAW.

In the pursuit of identity individuals seek the recognition of others and through dialectical processes moral beings tie their identity to others through binding themselves to certain institutions through some form of constitution. Kojeve (1980, p.10) asserts: 'To begin with, Self-Consciousness is simpleor-undivided Being for it-self; it is identical-to-itself by excluding from itself everything other [than itself]. Its essential reality and its absolute are for it $I$ [I isolated from everything and opposed to everything that is not I]'. However one subjective concept of self will one day confront another subjective concept of self each has only a subjective perspective of self: 
'And that is why his own subjective-certainty of himself does not yet possess truth [i.e. it does not yet reveal a reality - or in other words, an entity that is objectively, intersubjectively, i.e. universally recognised and hence valid' (ibid., pp.10-11). A subjective certainty of self is not enough because to ensure a full and truthful comprehension of self an external or other recognition is required. Putting these two perspectives together - (a) consciousness experienced subjectively, in self and (b) consciousness experienced objectively, in another - provides objective awareness of the self's subjectivity. 'Objective truth lies in ... mutual and consequently developed recognition of the other as a personality' (Hampsher-Monk, 1992, p.425). One must be recognised by others or transform the world into one that does recognise others, this may be achieved through an ethical community or constitution.

Recognition may also be related to nation-states in their quest for acknowledgement by other similar states. In the ethical community the individual has a right to recognition and the constitution guarantees that people are given the opportunity to develop. Indeed, the constitution is an institution and structure that provides meaning for our lives: 'we submit ourselves to a certain way of life, and as a result we come to see ourselves as persons of a certain kind ... By following the rules ... a person is making demands on the people around her to recognise her as a legitimate member of their group' and this provides recognition and identity (Ringmar, 1995, p.95). One may ask if the NAW is a means by which Wales is achieving this will it eventually be disseminated through the actions of the NAW throughout Wales in general?

Ringmar (1995) considers that in a period of state creation - as state identities are being formed - legal requirements are crucial. Indeed, features of the legal structure or constitution contribute to this: first, civil constitution gives substantive context to actions that political entities perform; and second it provides a standard by which political entities may be recognised as things of a certain kind. In the Welsh context we need to ask whether the NAW is an appropriate institution to ensure Welsh recognition and from whom or what the NAW membership primarily seeks recognition. Such may be investigated through a study of the newly established NAW.

\section{Discussing Welsh Political Identity}

This article is based on studies undertaken by Balsom (1985), Barry Jones and Balsom (2000), Bulmer et al (2001), Chaney et al (2001), Evans and Trystan (1999), Osmond (1985) Taylor and Thompson (1999), Williams (1971), Wyn Jones and Lewis (1999) and Wyn Jones and Trystan (1999; $2001)$. One may consider that '(d)evolution to Scotland and Wales is arguably the most significant change to the constitution of the United Kingdom in the twentieth century' (Barry Jones and Balsom, 2000, p.1). Indeed, devolution incorporates large-scale changes not only for Wales but for both the UK and EU government and legislatures as well. The case for a 
NAW gathered pace throughout the twentieth century and the Labour government argued that it needed to deal with the Welsh 'democratic deficit' and ensure those who control spending and set standards, 'for public services (were) answerable to the people they serve; and that a more responsive elected body will be better placed to promote economic prosperity and quality of life across Wales' (Welsh Office, 1997, p.7).

In 1925 Plaid Cymru was established against a backdrop of divisiveness and began its life not as a movement demanding independence but one that aimed to preserve the Welsh language. Two aspects of the ongoing debate regarding the place of Wales in the UK constitution were highlighted in the first Welsh day debate in the House of Commons in 1944. Aneurin Bevan argued that there were no solutions for the Welsh economy that were not problems elsewhere. However, in the same debate the Member of Parliament (MP) for Wrexham, Richard Roberts, considered that 'Wales is a nation which in its tradition, history, language and literature is quite distinct from England. There are many people in Wales who are more concerned about the culture of Wales than the economic life of Wales' (cited in Williams, 1971, p.16). Bevan was convinced of the need for a socialist strategy and central planning and saw no necessity for that strategy to have a Welsh dimension (Davies, 1994, p.609).

Osmond (1985) indicated that the Welsh were undergoing an identity crisis, that the diversity exemplified through locality posed a problem for Welsh identity. If Welshness was based on location, community and internal boundaries how can Wales be viewed as a whole? Balsom $(1985$, p.2) argued that any interpretation of Welsh identity is subjective because identity is 'a personal and individual characteristic ... which is especially responsive to environmental and group influences. Welsh identity must be defined as those who consider themselves to be Welsh are Welsh'. He used survey data collected in 1979 by the Welsh Election Study to indicate his three Wales model through a distinction between British and Welsh. The survey found that $57 \%$ of the Welsh electorate saw itself as Welsh, 34\% British and $8 \%$ English, consequently if we accept Balsom's premise (those that consider themselves Welsh are Welsh) in this context a Welsh identity exists. Furthermore, when the author examined the data relating to the three-Wales model (Welsh Wales, Y Fro Cymraeg and British Wales) over $60 \%$ of respondents perceived themselves as Welsh and $30 \%$ as British in the former categories and $50 \%$ as Welsh and $43 \%$ as British in the latter category (ibid). Osmond (1985) further argued that Welsh identity was inextricably linked with institutional structure e.g. on creation the main objective of Plaid Cymru was to 'infuse Welsh institutions, especially local government, with Welshness ... and where the necessary institutions did not exist, press for them to be created' (p.226). Indeed, one of the main objectives for Plaid Cymru was the creation of 'a legislative council elected by the men and women of Wales' (ibid.). In 1979 the Welsh people turned down the opportunity for an assembly, an institution which in 1997 they accepted. 
Wyn Jones and Trystan (2001, p.45) analysed data from the Welsh National Assembly Election Survey and concluded that with 'relatively few exceptions, non-voters appear to be apathetic rather than antipathetic towards the National Assembly'. However, a less optimistic view sees the timing of the referendum as essential to the 'yes' vote and wonders whether an assembly established on $25.2 \%$ of the vote would develop legitimacy across Wales in general (Wyn Jones and Lewis, 1999). Could an institution that most of the population thought immaterial engender an identity complementary to Wales in general? One may argue that identity in Wales is a very complex phenomenon. As a 'stateless nation' it has been said that 'Wales has not had a state apparatus to underpin a distinct identity. Rather its identity in the modern age has been created and recreated in the context of complex and often contradictory relationship with the English/British neighbour to the east' (Wyn Jones and Trystan, 1999, p.73).

Given these problems the question is has the new institution made any difference to Welsh identity? One might consider that the first place such changes will become apparent is within the NAW itself. Consequently this paper concentrates on the concept of political identity within the institution and from whom recognition is most required. To investigate these questions the author has undertaken an empirical study and, as noted above, uses Hegelian recognition to analyse the empirical data.

\section{An Empirical Study: Interviews and Survey Questions}

Morgan (1999) considered that the NAW was an institution that was developing its own cultural perspective and identity. This paper undertakes an empirical study of the NAW to ascertain whether Morgan's insights (especially regarding identity) could be substantiated. The author undertook a survey of AMs (60) and interviewed eight AMs and one civil servant to ascertain perceptions of political identity in the NAW and whether/how AMs thought this would develop. To understand from where identity recognition was sought concept questions were put to interviewees, which include: (a) Have there been new/evolutionary developments regarding relationships between the NAW and Whitehall over the past 2-3 years? (b) Have there been new/evolutionary developments regarding relationships between the NAW and European Union (EU) institutions over the last 2-3 years? Are there tensions between counterparts? (c) How much influence do AMs have at the national and/or EU level? In addition, direct questions were also asked that related to identity and recognition of self within the NAW and other recognition regarding identity in relation to Whitehall/Westminster and Brussels. The survey was made up of eighteen statements and asked AMs to agree or disagree on a Likert Scale. All AMs were sent a questionnaire (60 in total) - 24 were returned and five AMs responded with a letter, which informed the author that they did not have time to complete surveys. Overall, the interview questions and survey statements deal with two areas: first whether or not a distinct political identity exists in the NAW; and second if 
such an identity does exist from where is recognition sought? As noted above, to assist an analysis of these areas the author uses elements of Hegelian recognition.

\section{Political Identity: Self and Other Recognition}

This section of the article attempts an analysis of the interviews in relation to Hegelian concepts of self. As noted above, identity is considered as both subjective and objective, that individuals and institutions develop conceptualisations of identity in relation to self and other. For instance, Dafydd Wigley (Plaid Cymru) argued from a subjective perspective when he considered that the emergence of the NAW was the result of a developing consciousness, of the need for alternative structures to meet the different political aspirations that existed in Wales; aspirations that the political structures did not fulfil during the Conservative administration (interview with the author, 2001). In this way, as sought for many years by Plaid Cymru, the NAW was the recognition of the need for a concept of self in an institutional form. However, once the institution had taken form the problem becomes self-recognition in relation to what/who. Would it involve otherrecognition from Whitehall/Westminster or Brussels/Strasbourg?

Ron Davies (Labour) considered that even though devolution had provided Wales with the NAW little had changed between the UK and EU. He argued that in terms of the EU, in a formal sense (accepting the Committee of the Regions), little had changed. Formal representation of the NAW is made through UK institutions when dealing with the Council of Ministers (CofM). This is an institution to which the Welsh First Minister (FM) does not have automatic access. However, the FM can take the place of a UK minister if the issue directly affects Wales. On the other hand, Ron Davies argued that informal links between the NAW, the Welsh local authorities and EU institutions (especially the Commission) were developing. Moreover a Welsh European Centre (WEC) had been established in Brussels and this could be seen as an embryonic Welsh embassy. Furthermore, 'the European and External Affairs Committee aimed to provide strategic political guidance on European issues and to consider in detail those matters that impact directly on Wales' (Morgan, 2002, p.1, Para 3). However, the relationship with the UK was crucial and the committee would ensure that the UK position remains coherent while at the same time maintaining a dialogue with the EU (ibid., Paras 3 and 4). Ron Davies conceded that on an informal level a bid for recognition at the EU level was apparent but in a formal context such a bid was blocked by the dominant role of Whitehall/Westminster. However, when pressed on these issues he acknowledged that a form of multi-level governance existed through devolution and European integration, but for Wales this needed to be formalised in constitutional arrangements. Fundamentally, Ron Davies acknowledged that the NAW provided the basis of self-recognition in the formulation of identity but that other-recognition still needed to be developed (interview with the author, 2001). 
To an extent Dafydd Wigley disagreed with Ron Davies when he argued that, in theoretical terms, the NAW was supposed to go through the UK, but that in practice much went directly to Brussels. Lobbying UK ministers was problematic and some MPs considered that AMs were treading on their toes. This was not the case in Brussels where officials were used to working with regional representatives. Interaction with Brussels was growing as it was easier to influence relevant matters in Brussels than it was in London e.g. one may point to the partnership approach regarding the management of EU structural funds (Wigley interview with the author, 2001). Indeed, implementation of structural funds under Objective One is managed by the Economic Development Committee rather than the European Affairs Committee which may indicate a wider institutional interaction with Brussels. However, the precise reason for this is presently unclear and requires further investigation. In this context, recognition was already more apparent from Brussels than Whitehall and less consequential in terms of the latter than most AMs would usually admit. Self-recognition was developing through the evolving institution and other-recognition through the development of relationships with the UK and EU. However, as pointed out by Dafydd Wigley if further recognition was not realised by the UK then the NAW may change tack and pursue identity recognition from the EU. Overall, the NAW is primarily concerned with developing an identity that is recognised by national institutions and the EU with different levels of importance based around issues and political perspectives. This follows the conclusions identified by Bulmer $e t$ $a l$, which advised that the NAW exploit the UK and EU political spaces and influence policy as well as expanding Welsh placements in Brussels: 'Welsh devolved authorities have new opportunities to project themselves into the EU arena: whether through Whitehall or through the more limited direct options to Brussels itself. Both must be taken into account. These opportunities must be seized if devolution is to work' (Bulmer et al, 2001, p.161). Over the last year there have been developments regarding Welsh representation in Brussels and these are discussed in more detail below.

Andrew Davies (Labour) pointed out that 'under the Tories, the Secretary of State for Wales was a personal proving ground or an alternative power base' (interview with the author, 2001). The Welsh Office (WO) was largely administrative (a sort of fiefdom) led by the Secretary of State who represented government in Wales. Policy-making was undertaken in Whitehall and the WO was left under-resourced. This indicated limited recognition of Welsh needs and Welsh identity. However, according to Andrew Davies, in a post-devolution situation this had changed. Today the Secretary of State recognises the importance of the WO as a crucial element in the workings of the NAW and UK constitution (interview with the author, 2001). Indeed, the Secretary of State provided contact with the UK cabinet and was a means of ensuring other-recognition from Whitehall/Westminster.

In addition, Andrew Davies identified examples of self-recognition in the development of a political identity. Primary legislative powers were not 
granted which put an onus on the need for other-recognition from the UK. However, in the current situation Wales figured quite strongly in the legislative process. Legislation for Wales was dealt with differently before 1999 e.g. in the past legislation was developed in Wales by simply crossing out England and inserting Wales. Devolution dealt with both this and the 'democratic deficit'. Welsh solutions for Welsh problems meant Welsh policy. As Davies put it: 'Increasingly, we are doing things differently. We don't have primary legislative powers, so when we wanted changes that involve primary legislation we acted and so far we have been pretty successful in exploiting the current settlement to good effect' (interview with the author, 2001). This illustrated an opportunity for Wales to develop policies of its own and identify Welsh solutions to Welsh problems through self-recognition. However, it does mean a certain amount of otherrecognition from Whitehall/Westminster as this still existed as a form of control mechanism. Even though the NAW was constrained by its limited powers, these could be used to good effect both in the development of policy and in relations with Whitehall/Westminster and Brussels. In this way, the NAW was a means of developing self and other-recognition in each of the political environments.

The Principal Research Fellow (PRF) pointed out that there were ad hoc meetings and telephone conversations between English and Welsh equivalents. On the formal level the Department of Transport, Local Government and Regions (DTLR) invited officers to attend meetings as observers. This provided access to ongoing work and allowed Welsh input into the development of new work. Invitations though were not reciprocal and not thought necessary (this could indicate how important Welsh issues are perceived in Whitehall). In the main the Local Government Finance Department (LGDF) had a limited remit regarding the EU. In the UK however, they were developing a joint paper with the DTLR with a chapter dedicated to Wales. Indeed, this illustrated some self-recognition in the context of policy divergence between Wales and England and a concentration on other-recognition from Whitehall/Westminster.

Ron Davies argued that on one level little had changed between AMs and Whitehall. However, he also noted that tensions were beginning to develop as AMs 'find their feet in the ongoing interactions'. He suggested that in the main AMs remain 'timid in the face of Whitehall; they need to be more assertive' (interview with the author, 2001). Glyn Davies (Conservative) was of a similar mind-set. He thought that devolution was a process that needed to develop: 'Devolution needed leadership which it lacked. To date the institution had stood still. The NAW needed some form of national autonomy through evolutionary developments. The NAW was missing a distinct political identity because of the strong local government in Wales, which dominates the NAW along with a strong Whitehall presence indicative of the Labour party, which is obsessed with control' (interview with the author, 2001). Such provides an example of limited self-recognition 
and the need for this to intensify if other-recognition was to be achieved in the Whitehall/Westminster domain. Peter Black (Liberal) argued that Whitehall/Westminster initially guarded its territory jealousy, as it did not want to cede any more power to the NAW. However, he thought that recently things had become more relaxed. One may observe the genus of other-recognition in this context, but reluctance from Whitehall/Westminster in allowing this to develop.

In terms of the interaction between self and other recognition, in the context of the UK Peter Black pointed out that every time an act of parliament went through at Westminster the NAW gained in stature 'because whenever there is an act of parliament that relates to Wales, there is always secondary legislation. That secondary legislation is invariably given to us and we implement it, so in an evolutionary way we gain power through primary and secondary legislation' (interview with the author, 2001). Carwyn Jones (Labour) pointed out that because primary and secondary legislation were contradictory, in the recent Education Act there was a section for England and a section for Wales. This illustrated the evolutionary nature of legislation and substantiated the point made by Peter Black. However, both Carwyn Jones and Peter Black considered that the NAW should continue to press for powers similar to those held by Scotland. This, one might argue, is the only means by which full self and other-recognition can be accomplished.

In the context of the EU, Peter Black thought that AMs were learning how to deal with the new situation. From an EU perspective the NAW did not represent a state, so the EU primarily dealt with Whitehall/Westminster. However, NAW ministers were spending a lot more time negotiating with the EU on behalf of Wales and trying to give the EU a better understanding of what Wales encompassed. Black believes that: 'The NAW was learning how to deal with the EU whilst at the same time they were learning more about where we are coming from' (interview with the author, 2001). Carwyn Jones thought that on a formal level the EU was more remote than Whitehall/Westminster: 'I would have to say that most of the influence in terms of the EU tends to be through the UK government but there are occasions when AMs will jet off to Brussels for meetings' (interview with the author, 2002). The relationship with the EU was developing in an informal context and self and other recognition was developing in an interactive fashion. AMs and Welsh ministers understand the importance and relevance of self in relation to the EU and they stress the importance of Wales at the EU level to ensure other-recognition from this quarter.

Carwyn Jones indicated that the NAW incorporated a new legislature and executive, and on a formal level the executive took the lead regarding links with UK government and with the EU. However he thought the main objective should entail equality for Wales in the context of the EU 'because in many respects we are a member state' (interview with the author, 2002). 
He thought that the Committee of Regions worked well. But, there was a fundamental problem with the EU in the sense that it was un-democratic. It was not run by a Parliament so there were difficulties that needed to be solved from the bottom up. Indeed, Carwyn Jones would have preferred a constitution where Wales was an equal partner in the UK and EU structures. He said: 'We would look for equality with other devolved governments across Europe - like for example the Basque Country, Catalonia and so forth' (interview with the author, 2002). Osmond reported that the NAW had increased its involvement at the EU level when the First Minister, with nine other regions, responded to the White Paper on Regional Governance and called for greater 'involvement of the Committee of Regions in European policy formulation, with the European Commission consulting directly with regional governments rather than via member state governments' (Osmond 2002 , p.3). On the other, hand the Scottish Regional Committee has emphasised forming links at the national level, which may indicate that the Scottish Parliament perceives its role as an embryonic state whereas the NAW sees its future as a devolved region in the EU. In a comparative analysis between Wales and Scotland and other-recognition this could indicate that Scotland puts more emphasis on recognition from the EU than the UK. This may be supported by the differences between the Scottish Parliament and the NAW in terms of primary and secondary powers. However, this was not clear in the context of GM crops and is another area that requires further investigation.

Moreover, Carwyn Jones pointed out that on an informal level the NAW had close links with Brussels; that the NAW could not rely on the UK all of the time; and that AMs needed to be proactive if the Welsh voice was to be heard in Brussels. He also thought that even though Wales was not a large region it did have some influence at the EU level whereas, as noted above, he felt that at the UK level Welsh influence was substantial. An example of the difference may be found in the issue of GM crops. On the one hand, the NAW was anti-GM crops and against the European directive that attempted to deal with the issue. On the other hand, Whitehall/Westminster desperately attempted to convince the NAW that opposition should be removed. In dealing with this discrepancy the NAW used its secondary legislative powers and imposed a statutory distance between the different crops. In this way the NAW notified the European Commission that there was a problem with the GM directive; the UK government disagreed with the NAW but through devolution the NAW was able to deal with a problem that specifically affected Wales. Self-recognition in the context of the NAW and otherrecognition from both the UK and the EU are evident. However, in a formal context other-recognition from the UK is more apparent. Carwyn Jones acknowledged this when he considered that the relationship with the UK was far more important than that with the EU. The UK is more important because 'that is where most policy is still made for the whole of the country, because we (the NAW) lack primary powers our main engagement has to be with the 
UK government' (interview with the author, 2002). Overall, though, in terms of recognition from the both UK and the EU, the NAW had been rather successfụl.

Furthermore, Carwyn Jones indicated that initially Whitehall/Westminster did not take the NAW seriously but that this is not the case now and in Brussels it has been recognised that devolution has afforded the NAW some administrative capability. Fundamentally, the NAW underpins political identity in Wales: in fact it is central to it. If a Parliament existed in Scotland and an Assembly in Northern Ireland and nothing in Wales then the Welsh would be seen as English and Wales as an English region (Carwyn Jones interview with the author, 2002). The NAW is imperative. For Carwyn Jones, one of the drivers behind devolution was identity: 'If you are serious about selling yourself in the world you need to create a strong identity'. There is a need for self and other recognition - a self-recognition of one's identity that is also recognised by others. As Carwyn Jones says: 'If people have not heard of you they won't do business with you; Scotland and Ireland will reap it all! You either have an assembly or nothing, you cannot reject devolution twice and retain a Welsh Office and bloc grant ... Wales would have to be prepared to become a part of England completely, lose their identity completely' (interview with the author, 2002). Overall, he considered that recognition between Whitehall/Westminster and Cardiff should develop in an atmosphere of flexibility. The relationship should not be about power but mutual recognition and based around how one political centre may help the other (Jones, 2002).

William Graham (Conservative) considered that there was a lot of goodwill toward the NAW in Brussels and they were very complimentary about the Welsh European Centre (WEC). However, Wales was only part of a response from the UK and the NAW would not expect any special preference on political issues. AMs involve themselves at the EU level through the WEC and the European and External Affairs Committee, which was then headed by the First Minister and illustrated how seriously EU issues were taken. Graham explained: 'What we want (in Europe) is to be able to have influence at the earliest possible time. Directives are up for consultation years before they become law. When legislation affects Wales we want it to be in on the consultation from day one' (interview with the author, 2001). Overall he still thought that the NAW had little influence and limited formal recognition from either Whitehall/Westminster or Brussels. There is minimal recognition but Wales is still seen as an appendage.

Andrew Davies felt that there had been significant changes; devolution comprised the biggest constitutional change since the introduction of universal suffrage. The focus of political activity and of media groups shifted from Whitehall/Westminster to Cardiff and Edinburgh. A fundamental change was the shift in institutional focus; the Welsh Office (WO) was an institution that was largely administrative, whereas the NAW deals with policy and legislation. There were significant changes and developments 
between Whitehall and the NAW e.g. Whitehall had to recognise devolution. Following devolution Wales figured on their radar, they had to be aware of Wales as a factor. Prior to devolution both primary and secondary legislation was made by Whitehall with the WO involved in consultation. As Andrew Davies put it: 'The regulations would be made in Whitehall, passed on to the WO and in the main they would be put into the Minister's weekend box and he would sign it off. Devolution was instigated to deal with this inequity and increase public accountability and scrutiny' (interview with the author, 2001). Prior to devolution recognition from Whitehall/Westminster was limited. Post-devolution other-recognition had been forthcoming and AMs wanted to extend this.

On the other hand, Dai Lloyd (Plaid Cymru) thought that there had been limited developments between Whitehall and the NAW. He pointed out that Wales still had the same civil service as back in the colonial days (predevolution): 'For most of the civil servants here it was like being posted to Nigeria or India, you're in the DTI one week and in Wales or Northern Ireland the next. Frankly, until we get a more definite Welsh mindset in the civil service, there won't be any great evolutionary changes. In the main, Whitehall has major problems with the NAW. There is always a concentration on bad news and there is a lack of clarity regarding its powers and this is down to the inertia of Labour. There needed to be a shift away from colonialism' (interview with the author, 2001). Dai Lloyd emphasised development and the need for greater self-recognition as well as the pursuance of other-recognition. However, he did not conclude that otherrecognition should be solely sought from Whitehall/Westminster but primarily from the EU.

In this context, Dai Lloyd argued that Plaid Cymru was pro-EU and considered that Wales should be fully involved in the EU and eventually become a member state. Policy-making should be undertaken on a multi-level basis: 'Wales is one of the oldest European nations and ... decisions relating to the EU should be made at a European level, British things at a British level and those relating to Wales at the regional level. Increasingly, the EU is taking over legitimacy and in my view areas like macro-economic and environmental issues should come under its remit. Policy areas that fail to recognise national borders should be decided at the European Level and regional issues relating to Wales in Cardiff' (interview with the author, 2001).

Andrew Davies also thought that the EU was very important and that devolution provided a mechanism for the UK to join the EU mainstream and allow relationships on a regional level throughout the EU. A key theme in the referendum debate was a stronger voice in the EU and this struck a chord with many of the electorate. Since devolution the WEC has been set up in Brussels and this provided a Welsh presence and a sort of semi-civil service. As with other interviewees Andrew Davies thought that the WEC and EU networking as well as the European and External Affairs Committee were very important. Each aims to increase Wales' profile in the EU, which is an 
extremely high priority. Furthermore, ways of working with the CofR are continually being sought and other-recognition was not either/or it was both; other recognition was primarily sought from Whitehall/Westminster but this did not rule out activity in Brussels. Glyn Davies agreed with many of the points outlined above and argued that even though influence is carried by the nation-state, at the EU level, the NAW needed to develop relationships. As noted above, there have been developments regarding Welsh representation in the EU and further exploitation of political circumstances in Brussels. Indeed the NAW has become directly involved in the policy process and made this explicit by withdrawing from the WEC. This was because as Rhodri Morgan noted: 'we need to establish a stronger presence and a clearer profile in European institutions in Brussels, Strasbourg, Luxembourg and elsewhere ... We have considered the nature of our representation in Brussels and the need to establish a clearer identity and to answer the question who speaks for Wales in Brussels more clearly than in the past' (cited in Osmond, 2002, p.4). This, one may argue, is an intensification of self-recognition and an explicit bid for other-recognition from the EU quarter. As the NAW becomes more confident in its role at the EU level along with other regions it has begun to formulate policy to ensure otherrecognition from EU institutions.

The survey of AMs also investigated the changing relationships between the NAW, the UK and the EU. In respect of changing relationships at both an informal and formal level in the UK and EU, over $73 \%$ of respondents in the survey considered that the NAW was a starting point for the development of the existing arrangements between Westminster/Whitehall and EU. It is clear from the survey that AMs have a growing identity of self and, perhaps surprisingly, $86 \%$ saw themselves as important players in the UK and the EU. Interestingly, $64 \%$ perceived their relationship with the EU as central to their role even though their influence was limited. Furthermore $46 \%$ thought their role at the UK level was limited. In this context, $82 \%$ saw informal ad hoc relationships as most important at the EU level and 60\% at the UK level. $64 \%$ of respondents saw their relationship with the EU as central to the role of an AM and recognition from this quarter as imperative. Moreover, selfrecognition and other recognition in relation to Whitehall/Westminster can be observed in attitudes toward the role of the NAW and the present constitutional arrangements. For instance, in the survey $64 \%$ thought that the NAW should progressively move to tax-raising powers, $91 \%$ for greater legislative powers and $86 \%$ were in favour of constitutional change. In this context we can observe how the NAW has provided the basis and development of recognition and the growth of political identity. Overall, the interviews and survey identify distinct perspectives regarding identity in the NAW in terms of objective and subjective understandings of self. In general, AMs identify recognition from Whitehall/Westminster as paramount but argue that the EU is an important domain from which recognition should be sought either immediately of at some point in the future. 


\section{Concluding Observations}

This study has provided a mini-narrative regarding an evolving political identity in the formative NAW. Overall, AMs agreed that in some respects the establishment of the NAW has brought with it a stronger political identity and representation at both national and EU levels. However, there was a general perception that the limited powers of the NAW are not enabling it to deliver its basic objectives and in most areas it is highly dependent on Whitehall/Westminster. This limits both self-recognition and other recognition from Whitehall/Westminster.

Each of the interviewees considered that relationships with the UK and the EU would continue to evolve. The relationship with the UK was crucial and the EU very important. AMs will attempt to influence decision-making at all levels (multi-level governance). They indicated that recognition from the UK was seen as more immediate than that required from the EU. However, if UK recognition was not forthcoming or once it had been realised more emphasis would be placed on the EU. This is not to say that recognition from the EU was not sought; for instance the NAW sent a senior civil servant to Brussels to enable networking and relationship building with the European Commission and other European regions. Governance in the EU was changing and emphasis was increasingly put on the role of the regions. The European and External Affairs Committee intensifying its role in Brussels illustrated the emphasis on the role of regions in the EU policymaking process. Most AMs thought that the NAW was well placed to shape these changes and ultimately take advantage of them. This of course has implications for self and other recognition. In general AMs were concerned with developing an identity that is recognised by national institutions (Whitehall/Westminster). However, to differing degrees AMs perceived the EU as very important and recognition from Brussels as central to the NAW's concept of self and identity.

From the evidence outlined above one may argue that an interaction exists between individuals and institutions, which determines the direction and self-image of those involved in the institution. Furthermore, as self and other recognition grows in relation to the UK then it seems likely that further emphasis will be put on the EU. This study has identified a developing political identity in the NAW but to ascertain the existence of identity and the levels of recognition for the populace in general it would be necessary to incorporate a study of wider stakeholders. This study of the NAW provides an analysis of the political elite and identifies a form of conspicuous consumption. Overall, it may be argued that the Welsh do not express the political identity of the NAW in general and that the permeation of this throughout Welsh society may take years or never take root. If the latter case prevails then does it mean that the NAW will be/remain meaningless to the bulk of the Welsh populace? However, these issues need further analysis and following the recent election and subsequent Labour victory in Wales, these issues will need to be revisited. 
Note

A set of semi-structured interviews were undertaken with Peter Black AM, Andrew Davies AM (Economic Development Minister), Glyn Davies AM, Ron Davies AM, William Graham AM, Carwyn Jones (Open Government Minister), David Lloyd AM, Dafydd Wigley AM and a Principal Research Fellow (PRF) of the Civil Service.

\section{References}

Bangura, B. (2001), The Search for Identity: Ethnicity, Religion and Political Violence, Occasional Book No. 6, World Summit for Social Development.

Balsom, D. (1985), The Three Wales Model in J. Osmond (ed.) The National Question Again (Llandysul, Dyfed: Gomer Press), pp.1-17.

Barry Jones, J. and Balsom, D. (2000), The Road to the National Assembly for Wales (Cardiff: University of Wales Press).

Bulmer, S., Burch, M., Carter, C., Hogwood, P., and Scott, A. (2001), 'European Policy-Making Under Devolution: Britains New Multi-Level Governance', European Policy Research Unit (EPRU) Book No 1/01, Department of Government, Manchester University.

Chaney, P., Hall, T., and Pithouse, A. (eds) (2001), New Governance-New Democracy? (Cardiff: University of Wales Press).

Davies, J. (1994), A History of Wales (Harmondsworth: Penguin UK).

Evans, G., and Trystan, D. (1999), 'Why Was 1997 Different?', in B. Taylor and K. Thomson, Scotland and Wales: Nations Again? (Cardiff: University of Wales Press), pp. 95-117.

Hampsher-Monk, I. (1995), A History of Modern Political Thought (Oxford: Blackwell).

Hegel, G.W. (1967), Philosophy of Right (Tr. T.M. Knox) (New York: Oxford University Press).

Hegel, G.W. (1971), Philosophy of Mind (Tr. A.V. Miller) (Oxford: Clarendon Press).

Jones, C. (2002), Devolution in Practice. Institute of Public-Policy Research and Economic and Social Research Council Conference, 22 July, Carlton House, London.

Kant, I. (1987), Fundamental Principles of the Metaphysic of Morals (Tr. T.K. Abbott) (New York: Prometheus).

Kojeve, A. (1980), Introduction to the Reading of Hegel: lectures on the Phenomenology of Spirit (Tr. J.H. Nichols; ed. A. Bloom) (New York: Cornell University Press).

Morgan, K.O. (1999), 'Welsh Devolution: the Past and the future', in B. Taylor and K. Thomson (eds), Scotland and Wales: Nations Again? (Cardiff: University of Wales Press), pp.199-219.

Morgan, R. (2002), European Commission White Paper On Governance: Response From the First Minister On Behalf of the NAW (Cardiff: European and External Affairs Committee, National Assembly of Wales).

Osmond, J. (ed.) (2002), Engaging with Europe. Monitoring the National Assembly for Wales, Institute of Welsh Affairs in association with Strategy Wales (June).

Osmond, J (ed.) (1985), The National Question Again: Welsh Political Identity in the 1980s (Llandysul, Dyfed: Gomer Press).

Ringmar, E. (1995), 'The Relevance of International Law: a Hegelian interpretation of a peculiar 17th century pre-occupation', Review of International studies, Vol 21, pp.87-103. 
Sarup, M. (1996), Identity, Culture and the Postmodern World (Edinburgh: Edinburgh University Press).

Taylor, B. and Thomson, K. (eds) (1999), Scotland and Wales: Nations Again? (Cardiff: University of Wales Press).

Welsh Office (1997), A Voice for Wales (Cm. 3718) (London: The Stationery Office).

Williams, G. (1971), 'Language, literacy and nationality in Wales', History, Vol 56, pp.1-16.

Williams, G.A. (1991), When Was Wales? (Harmondsworth: Penguin UK).

Wyn Jones, R and Lewis, B. (1999), 'The 1997 Welsh Devolution Referendum', Politics, Vol 19, No 1, pp.37-46.

Wyn Jones, R and Trystan, D. (1999), 'The 1997 Welsh Referendum Vote', in B. Taylor and K. Thomson (eds), Scotland and Wales: Nations Again? (Cardiff: University of Wales Press), pp.65-93.

Wyn Jones, R and Trystan, D. (2001), 'Turnout, Participation and Legitimacy in the Politics of Post-Devolution Wales', in P. Chaney, T. Hall and A. Pithouse (eds), New Governance-New Democracy? (Cardiff: University of Wales Press), pp.1847. 